\title{
EFEKTIVITAS METODE ANALISIS GLASS UNTUK MENINGKATKAN KEMAMPUAN MEMBACA PERMULAAN PADA ANAK BERKESULITAN MEMBACA KELAS III SEKOLAH DASAR
}

\author{
Komarudin $^{1}$, Rahma Widyana ${ }^{2}$ \\ ${ }^{12}$ Program Magister Psikologi Profesi, Fakultas Psikologi \\ Universitas Mercu Buana Yogyakarta \\ 1.Komarfunniest21@gmail.com \\ 2rahma@mercubuana-yogya.ac.id
}

\begin{abstract}
Abstrak
Penelitian ini bertujuan untuk menguji efektivitas metode analisis Glass untuk meningkatkan kemampuan membaca permulaan pada anak berkesulitan membaca kelas III Sekolah Dasar.Hipotesis yang diajukan dalam penelitian ini adalah metode Analisis Glass efektif untuk meningkatkan kemampuan membaca permulaan pada anak berkesulitan belajar membaca kelas III Sekolah Dasar.Subjek penelitian adalah 5 orang siswa yang duduk di kelas 3 SD yang memiliki kemampuan membaca permulaan yang rendah.Teknik pengumpulan data menggunakanTes Kemampuan Membaca Awal.Analisis data dilakukan dengan menggunakan metode analisis statistik wilcoxon sign rank test dengan bantuan SPSS release 16. Hasil analisis data diperoleh probabilitas nilai $Z$ sebesar $-2,023$ pada taraf signifikansi sebesar $0,043(\mathrm{p}<0,05)$, yang artinya ada pengaruh signifikan penggunaan metode Analisis Glass terhadap peningkatan kemampuan membaca permulaan pada anak berkesulitan membaca kelas III SD. Kemampuan membaca permulaan pada anak berkesulitan membaca kelas III Sekolah Dasar setelah mendapatkan perlakuan akan meningkat. Hal ini dapat dapat diketahui dari kemampuan membaca permulaan pada post test lebihbaik dari pada pre test, yaitu dengan rerata peningkatan sebesar sebesar $12,82 \mathrm{kpm}$.
\end{abstract}

Kata kunci : metode analisis glass, kemampuan membaca permulaan

\section{EFFECTIVENESS OF GLASS ANALYSIS METHOD IN IMPROVING EARLY READING ABILITY ON THE READING DIFFICULTY IN THIRD GRADE OF ELEMENTARY SCHOOL}

\author{
Komarudin $^{1}$, Rahma Widyana ${ }^{2}$ \\ ${ }^{12}$ Program Magister Psikologi Profesi, Fakultas Psikologi \\ Universitas Mercu Buana Yogyakarta \\ ${ }^{1}$ Komarfunniest21@gmail.com \\ 2rahma@mercubuana-yogya.ac.id
}

\begin{abstract}
This study aims to investigate the effectiveness of Glass analysis methods to improve early reading ability in children with difficulty in third gradeof Elementary School. The hypothesis proposed in this research is the method of Glass Analysis is effective to improve the early reading ability in children with learning reading difficulties in the third grade of elementary school. The research subjects were 5 students who were in third grade of elementary school who had low reading ability. Data collection techniques used is the Early Reading Ability Test. Data analysis was done by using statistical analysis method wilcoxon sign rank test with the help of SPSS release 16. The result of data analysis obtained the probability of $Z$ value equal to $-2,023$ at significance level equal to $0,043(\mathrm{p}<0,05)$, meaning there is significant influence in the use of Glass Analysis method on improving the early reading ability of the children reading difficulty in third grade of Elementary School. Early reading ability in children with reading difficulty inthird
\end{abstract}


grade of elementary school after receiving the treatment will increase. It is known from the early reading ability of the post-test is better than the pre-test, with the increasing average of 12.82 $\mathrm{kpm}$.

Keywords: glass analysis method, early reading skill

\section{PENDAHULUAN}

Bersamaan dengan kemajuan ilmu dan teknologi yang pesat, manusia harus terus menerus memperbarui pengetahuan dan keterampilannya. Pengetahuan dan keterampilan tersebut sebagian besar diperoleh melalui membaca (Abdurrahman, 2010).Membaca merupakan kemampuan akademik yang penting dan merupakan dasar untuk semua pembelajaran akademik (Herwell, 2008). Dikarenakan pentingnya membaca, maka menurut Lerner (dalam Abdurrahman, 2010), anak harus belajar membaca supaya pada akhirnya dapat memiliki kemampuan membaca untuk belajar.

Pada umumnya, anak mulai belajar membaca ketika di awal kelas sekolah dasar (1, 2, dan $3 \mathrm{SD})$, yang disebut dengan membaca permulaan (Jamaris, 2014). Kemampuan membaca permulaan didefinisikan sebagai kapabilitas menterjemahkan isi tulisan atau simbol verbal yang tercetak menjadi kata-kata yang memiliki makna yang mencakup pengenalan huruf sebagai lambang bunyi-bunyi bahasa dan dilanjutkan dengan pemahaman isi bacaan. Untuk mengukur tingkat kemampuan membaca permulaan, dapat dilihat berdasarkan aspek kecepatan dan pemahaman. Kecepatan membaca merupakan rata-rata jumlah kata yang dapat dibaca dalam setiap menit ( $\mathrm{kpm})$. Pemahaman yaitu prosentase jawaban yang benar atas pertanyaan-pertanyaan yang berkaitan dengan materi bacaan (Tampubolon, 1990). Lebih lanjut Widiatmoko (2011), menetapkan kemampuan membaca bagi anak kelas Sekolah Dasar sebesar 80-140 kpm. Hal ini berarti, jika pada siswa SD kemampuan membacanya di bawah $80 \mathrm{kpm}$, maka siswa tersebut diindikasikan memiliki kemampuan membaca yang cenderung rendah.

Apabila anak pada usia sekolah permulaan (kelas 1, 2, dan 3 SD) tidak segera memiliki kemampuan membaca permulaan, maka anak tersebut akan mengalami banyak kesulitan dalam mempelajari berbagai bidang studi pada kelas-kelas berikutnya (Lerner dalam Abdurrahman, 2010). Ketidakmampuan dalam membaca permulaan ini juga dapat dialami oleh anak yang memiliki IQ normal. Anak-anak tersebut mempunyai keterbelakangan membaca dibanding temanteman sebayanya di sekolah dasar (Dumont dalam Monks dkk, 2006).

Fakta ini ditemui pada 3 anak yang duduk di kelas 3 SD 3 Sedayu dan 2 anak yang duduk di kelas 3 SD 1 Kadipiro, yaitu RMN, MRP, NA, RAN, dan AIR. Kelima anak tersebut memiliki IQ dalam kategori normal (IQ 90-110) berdasarkan hasil tes WISC. Menurut Soemantri (2007), seharusnya anak dengan IQ normal memiliki kemampuan membaca yang baik. Namun pada kenyataannya berdasarkan hasil tes alat 
kemampuan membaca awal yang disusun oleh Widyana, Safitri, dan Purnamasari (2010) yang diberikan pada kelima anak tersebut, menunjukkan hasil bahwa kemampuan membaca kelima anak tersebut cenderung rendah (kurang dari $80 \mathrm{kpm}$ ).

Menurut Jamaris (2014), kemampuan membaca yang rendah dipengaruhi oleh 2 faktor, yaitu proses sensomotor dan kemampuan kognitif. Proses sensomotor yang berperan dalam pembentukan kemampuan membaca, yaitu kemampuan diskriminasi auditori (kemampuan membedakan bunyi dari huruf yang digunakan dalam membaca), kemampuan diskriminasi visual (kemampuan membedakan bentuk-bentuk huruf yang ada dalam bacaan), dan kemampuan mengintegrasikan diskriminasi visual dan diskriminasi auditori. Sedangkan kemampuan kognitif berhubungan dengan simbolisasi (memahami bahwa simbol-simbol grafis mengandung arti dalam bahan bacaan) dan urutan simbol grafis yang disusun akan membentuk kata dan kalimat yang mengandung makna. Dalam hal ini, fakta yang ditemukan pada subjek RMN, MRP, NA, RAN, dan AIR, menunjukkan bahwa kelima anak tersebut memiliki permasalahan dalam sensomotor yang ditunjukkan dari hasil tes Marrianna Frostig Developmental Test of Visual Perception dan Tes Tugas Kategorisasi Bunyi yang disusun oleh Widyana (2006).

Berdasarkan hasil dari Marrianna Frostig Developmental Test of Visual Perception, RMN memiliki skor Perceptual Quotient (PQ) sebesar 75 (borderline), MRP sebesar 87 (di bawah rata-rata), NA sebesar 78 (borderline), RAN sebesar 83 (di bawah ratarata), dan AIR sebesar 75 (borderline) yang berarti kelima subjek memiliki kemampuan persepsi visual yang lebih rendah dibandingkan dengan anak-anak lain seusianya. Akibatnya dengan memiliki persepsi visual yang rendah maka kelima anak tersebut cenderung akan mengalami hambatan dalam membedakan bentuk-bentuk huruf dalam bacaan (Sulo dkk, 2013).

Sementara itu berdasarkan hasil Tes Tugas Kategorisasi Bunyi yang disusun oleh Widyana (2006), menunjukkan bahwa RMN memiliki skor 9 (di bawah rata-rata), MRP memiliki skor 8 (di bawah rata-rata), NA memiliki skor 8 (di bawah rata-rata), RAN memiliki skor 8 (di bawah rata-rata), dan AIR memiliki skor 9 (di bawah rata-rata); yang berarti kelima anak tersebut memiliki kemampuan terhadap diskriminasi auditori yang rendah. Menurut Sulo dkk (2013), apabila anak memiliki diskriminasi auditori yang rendah, maka anak akan kesulitan dalam membedakan bunyi dari huruf dalam membaca.

Kurangnya kemampuan dalam melakukan persepsi visual dan auditori akan menjadikan anak kurang mampu dalam mengintegrasikan diskriminasi visual dan auditori, sehingga akan mempengaruhi proses decoding (Jamaris, 2014). Pemecahan sandi/decodingdidefinisikan sebagai menentukan bunyi yang berhubungan dengan suatu kata tertulis secara tepat. Jika anak tidak melakukan decoding/pemecahan sandi tulisan secara efisien, maka anak akan kesulitan dalam membaca (Mulyadi, 2010).Terlebih 
pada anak yang duduk di akhir kelas 2 SD atau awal kelas 3 SD, seharusnya sudah mampu melakukan decoding secara otomatis (Chall, dalam Kumara 2014).

Menurut Resinski (dalam Kumara 2004), terdapat beberapa bentuk kesalahan/akurasi dalam pengucapan bahasa tulis ke bahasa lisan (decoding), yaitu: menambahkan huruf atau kata yang tidak ada dalam tulisan, tidak mengucapkan bunyi huruf atau kata yang seharusnya diucapkan, walaupun huruf atau kata tersebut terdapat dalam teks, dan membalik posisi huruf. Sementara itu, Hanifah (2013) lebih memetakan kesalahan dalam proses decoding pada kesalahan membaca dua suku kata, tiga suku kata atau kata berimbuhan, kata berdisfrog, kata "ng" dan "ny", dan kata berkluster. Adapun karakteristik kesalahan membaca yang dilakukan RMN, MRP, NA, RAN, dan AIR melalui Tes Kemampuan Membaca Awal yang disusun oleh Widyana, Safitri, dan Purnamasari (2010) dapat diketahui bahwa bentuk kesulitan membaca yang dialami oleh RMN, MRP, dan NA berupa kesalahan decoding dalam membaca dua suku kata, tiga suku kata atau kata berimbuhan, kata berdisfrog, kata "ng" dan "ny", dan kata berkluster. Sementara itu RAN mengalami kesalahan dalam membaca dua suku kata, tiga suku kata atau kata berimbuhan, kata "ng" dan "ny", dan kata berkluster; tetapi tidak mengalami kesalahan pada kata berdisfrog. Sedangkan AIR mengalami kesalahan pada membaca tiga suku kata atau kata berimbuhan, kata berdisfrog, kata "ng" dan "ny", dan kata berkluster; akan tetapi tidak mengalami kesalahan dalam membaca dua suku kata.Menurut Abdurrahman (2010), terdapat 3 metode yang dapat digunakan untuk meningkatkan kemampuan membaca permulaan pada anak berkesulitan membaca, yaitu Metode Fernald, Metode Gilinghham, dan Metode Analisis Glass. Dikarenakan permasalahan membaca RMN, MRP, NA, RAN, dan AIR dipengaruhi oleh faktor sensomotor yang menjadikan kelima anak tersebut kurang mampu mengintegrasikan diskriminasi visual dan diskriminasi auditori yang berakibat anak kesulitan melakukan pemecahan sandi/decoding dengan baik. Maka diperlukan suatu metode untuk meningkatkan kemampuan decoding anak, sehingga kemampuan membacanya meningkat. Menurut Abdurrahman (2010), salah satu metode yang diasumsikan dapat digunakan untuk meningkatkan kemampuan membaca anak adalah metode Analisis Glass. Dipilihnya metode Analisis Glass karena metode ini memiliki asumsi dasar bahwa pemecahan sandi (decoding) mendasari membaca (reading). Artinya anak akan mengalami kesulitan membaca, apabila tidak mampu melakukan pemecahan sandi/decoding.

Dalam penelitian ini, langkah-langkah metode Analisis Glass yang digunakan mengacu pada pendapat Mather \& Goldstein (2012), yaitu:

1. Mengidentifikasi keseluruhan kata, huruf, dan bunyi kelompok huruf.

Pada tahap pertama, fasilitator memperlihatkan sebuah kartu kata, lalu membaca kartu tersebut secara 
keseluruhan, kemudian anak diminta menirukan kata tersebut.

2. Mengucapkan bunyi-bunyi kelompokkelompok huruf dan huruf, serta bertanya kepada anak huruf apa yang menghadirkan bunyi.

Pada tahap ini, fasilitator menganalisa keseluruhan kata dengan menunjukkan satu persatu huruf sambil mencontohkan bunyi huruf dan anak menirukan. Selanjutnya anak diminta membaca bunyi huruf yang ditunjukkan tutor secara acak dengan bertanya kepada anak "bagaimana bunyi huruf tersebut."

3. Menyajikan kepada anak, huruf atau kelompok huruf dan meminta anak untuk mengucapkannya.

Pada tahap ini, anak diminta membaca kelompok huruf secara mandiri, namun tetap dengan bimbingan fasilitator. Kelompok huruf dalam tahap ini tidak dieja.

4. Mengambil beberapa huruf pada kata yang tertulis dan anak diminta mengucapkan bunyi kelompok huruf yang masih tersisa.

Tahap ini adalah mengeliminasi beberapa huruf dari kata. Fasilitator menghilangkan salah satu huruf dari kata yang sudah disajikan sebelumnya, dan meminta anak untuk membacanya. Selanjutnya tutor kembali melengkapi kata yang dihilangkan sebelumnya dengan huruf yang berbeda.

5. Menanyakan kepada anak tentang keseluruhan kata.

Pada tahap terakhir, fasilitator kembali menyajikan kata yang disajikan pada tahap pertama secara utuh dan anak diminta untuk membacanya.

Berdasarkan model umum imajeri, kesadaran, dan kognisi yang dibuat oleh David F Marks (dalam Suharnan, 2005), ketika anak belajar membaca dengan menggunakan langkah-langkah metode Analisis Glass, maka terjadi pemrosesan informasi dalam ingatan anak tersebut. Diawali ketika fasilitator menampilkan kartu kata yang diikuti dengan membaca kartu kata dan mencontohkan bunyi huruf yang membentuk kata tersebut, merupakan bentuk dari stimulus sensori visual dan auditori yang selanjutnya diterima dan dipersepsi melalui alat indera anak (mata dan telinga). Stimulus tersebut dipersepsi anak dan masuk dalam ingatan / kesadaran dan dalam waktu yang singkat apa yang dipersepsi itu dapat ditimbulkan kembali sebagai memory output. Hal ini terlihat pada point 2,3,4, dan 5 dalam langkah metode Analisis Glass. Bahwa kata dan huruf yang sudah masuk ke dalam ingatan anak dimunculkan kembali melalui tahapan: anak diminta membaca bunyi huruf yang ditunjukkan fasilitator secara acak, membaca kelompok huruf secara mandiri dan tidak dieja, membaca kata yang sebagian hurufnya telah dieliminasi, dan membaca kembali keseluruhan kata yang disajikan pada tahap pertama secara utuh. Rangkaian proses ini disebut sebagai short term memory.

Meskipun demikian,menurutMarks (dalam Suharnan, 2005), kata yang telah dipersepsi oleh anak tidak seluruhnya langsung ditimbulkan dalam kesadaran sebagai memory output, tetapi disimpan dalam gudang ingatan melalui pencatatan (encoding). Pada 
suatu waktu apabila diperlukan melalui retreival (mencari kembali informasi dalam gudang ingatan), kata tersebut dapat ditimbulkan kembali sebagai memory output. Artinya ketika anak mendapatkan kata yang sama bentuk atau jenisnya, maka secara otomatis kata tersebut akan direspon oleh ingatan dengan cara melakukan retrieval, sehingga anak akan secara otomatis mampu membaca kata yang sudah disimpan dalam gudang ingatannya tersebut. Proses menimbulkan kembali stimulus (kata) yang tersimpan dalam gudang ingatan ke dalam kesadaran ini disebut sebagai long therm memory. Hal ini mengindikasikan, bahwa kata-kata yang dipelajari anak melalui metode analisis Glass akan dimunculkan kembali secara cepat (20-30 detik) ketika proses pemberlakuan metode analisis Glass pada subjek dan juga akan disimpan dalam gudang ingatan, sehingga ketika kata-kata tersebut dimunculkan kembali dalam Tes Kemampuan Membaca, maka anak akan mampu merespon/membacanya dengan tepat.

Ketepatan dalam membaca kata ini diasumsikan bahwa melalui langkah-langkah metode Analisis Glass, kesalahan dalam membaca kata dapat dikurangi atau dihilangkan karena anak telah mampu melakukan decoding dengan akurat dan tepat. Menurut teori otomatisitas yang dikemukakan oleh LaBerge dan Samuels (dalam Kumara, 2014), decoding secara akurat artinya membaca secara tepat tanpa mengalami kesalahan. Sedangkan decoding dengan otomatis, artinya membaca secara cepat tanpa banyak mengeluarkan upaya mental dalam memusatkan perhatian kepada huruf -huruf yang menyusun sebuah kata. Semakin akurat dan otomatis dalam melakukan decoding, maka akan meningkatkan kecepatan membaca anak. Selain itu, menurut teori otomatisitas, apabila anak mampu melakukan proses decoding secara akurat dan cepat, maka tersisa banyak energi mental yang akan digunakan dalam memahami isi pesan yang terkandung dalam bacaan atau meningkatkan pemahaman. Melalui peningkatan kecepatan membaca dan pemahaman ini, maka diasumsikan kemampuan membaca anak akan meningkat. Hal ini didasarkan pada pendapat dari Tampubolon (1990), bahwa kemampuan membaca dibentuk oleh 2 aspek, yaitu kecepatan membaca dan pemahaman, sehingga apabila kedua aspek tersebut meningkat, maka kemampuan membaca anak juga akan mengalami peningkatan.

Berdasarkan uraian di atas, maka diajukan hipotesis sebagai berikut: metode Analisis Glass efektif untuk meningkatkan kemampuan membaca permulaan pada anak berkesulitan belajar membaca kelas III Sekolah Dasar. Kemampuan membaca permulaan pada anak berkesulitan membaca kelas III Sekolah Dasar setelah mendapatkan perlakuan akan meningkat.

\section{METODE}

Variabel Tergantung dalam penelitian ini adalah kemampuan membaca permulaan. Sementara variabel Bebas adalah metode Analisis Glass. Kemampuanmembaca permulaan didefinisikan sebagaikapabilitas menterjemahkan isi tulisan atau simbol verbal 
yang tercetak menjadi kata-kata yang memiliki makna yang mencakup pengenalan huruf sebagai lambang bunyi-bunyi bahasa dan dilanjutkan dengan pemahaman isi bacaan. Adapun aspek yang yang digunakan untuk mengukur kemampuan membaca permulaan mengacu pada pada aspek yang dikemukakan oleh Tampubolon (1990), yaitu aspek kecepatan dan pemahaman.

Metode Analisis Glass merupakan suatu metode pengajaran melalui pemecahan sandi kelompok huruf dalam kata yang bertolak dari asumsi yang mendasari membaca sebagai pemecahan sandi atau kode tulisan. Adapun langkah- langkah metode analisis Glass yang digunakan dalam penelitian ini mengacu pada pendapat yang dikemukakan oleh Mather \& Goldstein (2012), yang terdiri dari: mengidentifikasi keseluruhan kata, huruf, dan bunyi kelompok huruf; mengucapkan bunyibunyi kelompok- kelompok huruf dan huruf, serta bertanya kepada anak huruf apa yang menghadirkan bunyi; menyajikan kepada anak, huruf atau kelompok huruf dan meminta anak untuk mengucapkannya; mengambil beberapa huruf pada kata yang tertulis dan anak diminta mengucapkan bunyi kelompok huruf yang masih tersisa; serta menanyakan kepada anak tentang keseluruhan kata.

Subjek dalam penelitian ini adalah 5 orang siswa kelas 3 SD yang sekolah di Sekolah Penyelenggara Pendidikan Inklusif (SD 3 Sedayu dan SD 1 Kadipiro) yang mengalami kesulitan belajar membaca dengan karakteristik: duduk di kelas 3 SD, memiliki IQ dalam kategori rata - rata berdasarkan Tes WISC, subjek mengalami kesulitan membaca permulaan yang dapat dilihat dari hasil tes kemampuan membaca awal yang disusun oleh Widyana, Safitri, dan Purnamasari (2010) berdasarkan aspek kecepatan dan pemahaman, yaitu kemampuan membaca di bawah $80 \mathrm{kpm}$ dan kesulitan membaca yang dialami subjek adalah kesulitan dalam melakukan pemecahan sandi/ decoding.

Metode yang digunakan dalam penelitian ini adalah metode eksperimen dengan rancangan eksperimen one group pretest-postest design, yaitu di awal penelitian dilakukan pengukuran terhadap Variabel Tergantung (kemampuan membaca permulaan) yang telah dimiliki subjek. Setelah diberikan manipulasi/VB (metode Analisis Glass), dilakukan pengukuran kembali terhadap VT dengan alat ukur yang sama (Seniati dkk, 2014).

Alat ukur yang digunakan sebagai metode pengumpulan data dalam penelitian ini, yaitu dengan Tes Kemampuan Membaca Awal yang disusun Widyana, Safitri, dan Purnamasari (2010).

Metode analisis data yang digunakan adalahteknik analisis Wilcoxon Sign Rank Test, untuk melihat perubahan kemampuan membaca permulaan subjek sebelum dan sesudah intervensi diberikan. Skor individu yang diperoleh digunakan sebagai dasar analisis. Apabila ada perbedaan antara skor pretest dan skor posttest dimana skor posttest lebih tinggi secara signifikan, maka dapat disimpulkan bahwa metode analisis Glass meningkatkan kemampuan membaca.

\section{HASIL DAN PEMBAHASAN}


Hasil perhitungan data empirik skor kemampuan membaca permulaan menunjukkan bahwa skor kemampuan membaca permulaan sebelum perlakuan yang diperoleh subjek penelitian, yaitu skor terendah 10,94 kpm dan skor tertinggi sebesar $14,99 \mathrm{kpm}$ dengan rerata 13,19 kpm. Sedangkan skor kemampuan membaca permulaan setelah perlakuan yang diperoleh subjek, yaitu skor terendah 17,94 kpm dan skor tertinggi sebesar $30,15 \mathrm{kpm}$ dengan rerata 26,01 kpm. Hal ini menunjukkan ada kenaikan rerata kemampuan membaca sebesar 12,82 kpm. Artinya kelima subjek mengalami peningkatan skor kemampuan membaca permulaan setelah mendapatkan perlakuan. Hasil perhitungan data empirik skor skor kemampuan membaca permulaan sebelum dan sesudah perlakuan dapat dilihat pada Tabel 1.

Tabel 1. Descriptive Statistic Kemampuan Membaca

\begin{tabular}{lllllc}
\hline & N & Min & Max Mean & $\begin{array}{c}\text { Std. } \\
\text { Deviation }\end{array}$ \\
\hline membaca prates & 5 & 10,94 & 14,99 & 13,19 & 1,74 \\
membaca post tes & 5 & 17,94 & 30,15 & 26,01 & 4,87 \\
\hline
\end{tabular}

Meningkatnya kemampuan membaca permulaan kelima subjek dikarenakan ada peningkatan 2 aspek kemampuan membaca permulaan yang dikemukakan oleh Tampubolon (1990), yaitu kecepatan dan pemahaman.

Berdasarkan data empirik menunjukkan skor aspek kecepatan membaca secara keseluruhan sebelum perlakuan yang diperoleh subjek penelitian, yaitu skor terendah 19,15 $\mathrm{kpm}$ dan skor tertinggi sebesar 23,86 kpm dengan rerata 22,15 kpm. Sedangkan skor aspek kecepatan membaca setelah perlakuan yang diperoleh subjek, yaitu skor terendah $24,16 \mathrm{kpm}$ dan skor tertinggi sebesar 36,39 $\mathrm{kpm}$ dengan rerata $31,73 \mathrm{kpm}$. Hal ini menunjukkan ada kenaikan rerata kecepatan membaca sebesar 9,58 kpm. Sementara itu data empirik juga menunjukkan secara keseluruhan terlihat skor aspek pemahaman sebelum perlakuan yang diperoleh subjek penelitian, yaitu skor terendah $57,14 \%$ dan skor tertinggi sebesar $62,86 \% \mathrm{kpm}$ dengan rerata 59,42\%. Sedangkan skor aspek pemahaman setelah perlakuan yang diperoleh subjek, yaitu skor terendah $74,28 \% \mathrm{kpm}$ dan skor tertinggi sebesar $85,71 \%$ dengan rerata $81,14 \%$. Hal ini menujukkan ada kenaikan rerata pemahaman sebesar $21,72 \%$.

Berdasarkan hasil analisis kuantitatif dengan menggunakan uji non parametrik wilcoxon signed ranks test menunjukkan skor $\mathrm{Z}$ sebesar $-2,023(\mathrm{p}<0,050)$, yang artinya ada perbedaan signifikan antara kemampuan membaca permulaan subjek sebelum dan sesudah diberikan perlakuan dengan menggunakan metode Analisis Glass. Hal ini menunjukkan bahwa kemampuan membaca permulaan pada anak berkesulitan membaca kelas III Sekolah Dasar setelah mendapatkan perlakuan meningkat dibandingkan sebelum diberikan perlakuan. Peningkatan rerata kemampuan membaca permulaan tersebut terlihat dalam analisis deskriptif, yaitu sebesar $12,82 \mathrm{kpm}$.

Secara kualitatif dapat diketahui bahwa pada awal proses pemberian perlakuan terhadap kelima subjek dengan menggunakan metode Analisis Glass, tampak bahwa 
fasilitator dapat menjalin komunikasi yang hangat dengan cara menanyakan kabar subjek dan dilanjutkan dengan memperkenalkan diri kepada seluruh subjek, sehingga seluruh peserta pelatihan mampu memberikan respon dengan menjawab pertanyaan fasilitator dan bergantian memperkenalkan diri. Adanya raport yang baik ini, telah membantu fasilitator dalam melaksanakan tahapan pemberian perlakuan selanjutnya.

Berdasarkan model pemrosesan kognisi yang dikemukakan oleh Marks (dalam Suharnan, 2005) menunjukkan bahwa, ketika kelima subjek belajar membaca dengan menggunakan metode Analisis Glass, maka terjadi pemrosesan informasi dalam ingatan subjek. Diawali ketika fasilitator menampilkan kartu kata yang diikuti dengan membaca kartu kata dan mencontohkan bunyi huruf yang membentuk kata tersebut, merupakan bentuk dari stimulus sensori visual dan auditori yang selanjutnya diterima dan dipersepsi melalui alat indera anak (mata dan telinga). Stimulus tersebut dipersepsi anak dan masuk dalam ingatan / kesadaran dan dalam waktu yang singkat apa yang dipersepsi itu dapat ditimbulkan kembali sebagai memory output yang tampak ketika subjek diminta membaca bunyi huruf yang ditunjukkan fasilitator secara acak, membaca kelompok huruf secara mandiri dan tidak dieja, membaca kata yang sebagian hurufnya telah dieliminasi, dan membaca kembali keseluruhan kata yang disajikan pada tahap pertama secara utuh. Meskipun demikian, kata yang telah dipersepsi oleh subjek tidak seluruhnya langsung ditimbulkan dalam kesadaran sebagai memory output, tetapi disimpan dalam gudang ingatan melalui pencatatan (encoding). Pada suatu waktu apabila diperlukan melalui retreival (mencari kembali informasi dalam gudang ingatan), kata tersebut dapat ditimbulkan kembali sebagai memory output. Artinya ketika subjek mendapatkan kata yang sama bentuk atau jenisnya, maka secara otomatis kata tersebut akan direspon oleh ingatan dengan cara melakukan retrieval, sehingga subjek akan secara otomatis mampumembaca kata yang sudah disimpan dalam gudang ingatannya tersebut.

Hal ini mengindikasikan, bahwa katakata yang dipelajari subjek melalui metode Analisis Glass akan dimunculkan kembali secara cepat (20-30 detik) pada saat proses penerapan metode analisis Glass dan juga akan disimpan dalam gudang ingatan, sehingga ketika kata-kata tersebut dimunculkan kembali pada saat Tes Kemampuan Membaca Permulaan setelah perlakuan, maka subjek akan mampu membacanya dengan tepat. Akibatnya kesalahan membaca kata yang dialami kelima subjek ketika Tes Kemampuan Membaca Pemulaan menjadi berkurang setelah subjek diberi perlakuan dengan menggunakan metode analisis Glass.

Hal ini terlihat dalam analisis kualitatif, seluruh subjek mengalami penurunan jumlah kesalahan membaca kata dalam Tes Kemampuan Membaca Permulaan setelah perlakuan, yaitu RMN mengalami penurunakan kesalahan membaca kata sebanyak 32 kata, MRP sebanyak 28 kata, NA sebanyak 19 kata, RAN sebanyak 14 kata, dan AIR sebanyak 20 kata. Bahkan melalui metode 
Analisis Glass ini, juga mampu meniadakan kesalahan membaca kata dengan 2 suku kata yang dilakukan subjek RMN, MRP, NA, dan RAN pada saat Tes Kemampuan Membaca Permulaan sebelum perlakuan. Selain itu juga mampu meniadakan kesalahan baca pada 3 suku kata atau kata berimbuhan pada subjek RMN, AIR, RAN, MRP, dan mampu meniadakan kesalahan membaca kata berdisfrog pada subjek AIR dan NA. Sementara pada kata 'ng' dan 'ny', serta kata berkluster, metode Analisis Glass mampu menurunkan tingkat kesalahan membaca kelima subjek penelitian.

Berkurangnya atau hilangnya kesalahan dalam membaca kata tersebut pada saat Tes Kemampuan Membaca Permulaan setelah perlakuan, menunjukkan bahwa kelima subjek mengalami peningkatan dalam melakukan proses decoding secara akurat dan otomatis. Menurut Kumara (2014), decoding secara akurat artinya membaca secara tepat tanpa mengalami kesalahan. Sedangkan decoding dengan otomatis, artinya membaca secara cepat tanpa banyak mengeluarkan upaya mental dalam memusatkan perhatian kepada huruf-huruf yang menyusun sebuah kata. Semakin akurat dan otomatis dalam melakukan decoding, maka akan meningkatkan kecepatan membaca subjek. Peningkatan kecepatan membaca tampak pada tabel statistik deskriptif, bahwa terjadi peningkatan rerata kecepatan membaca subjek setelah perlakuan sebesar 9,58 kpm.

Selain itu, menurut teori otomatisitas yang dikemukakan oleh LaBerge dan Samuels (dalam Kumara, 2014), apabila subjek mampu melakukan proses decoding secara akurat dan cepat, maka akan mudah memahami isi pesan terkandung dalam bacaan atau meningkatkan pemahaman. Peningkatan pemahaman isi bacaan pada kelima subjek tampak pada tabel statistik deskriptif, yang menunjukkan terjadi peningkatan rerata pemahaman subjek setelah perlakuan sebesar $21,72 \%$.

Mengacu pada hal tersebut, tampak bahwa metode Analisis Glass mampu meningkatkan kecepatan membaca dan pemahaman subjek. Peningkatan rerata pemahaman subjek sebesar 21,72 lebih tinggi dibandingkan peningkatan rerata kecepatan membaca sebesar 9,58. Hal ini dikarenakan kelima subjek masih mengalami kesulitan decoding dalam membaca kata dengan huruf 'ng' dan 'ny', serta kata berkluster, sehingga ketika subjek menemui kata dengan huruf 'ng' dan 'ny', serta kata berkluster pada saat membaca materi Tes Kemampuan Membaca Awal setelah perlakuan, maka subjek akan cenderung mengejanya. Hal ini mengakibatkan, subjek cenderung mengurangi kecepatan dalam membaca kata tersebut, sehingga dapat mengurangi kecepatan membaca subjek.

Selain itu, hasil penelitian menunjukkan bahwa rerata peningkatan pemahaman lebih tinggi dibandingkan kecepatan membaca, hal ini disebabkan karena meskipun subjek tidak membaca seluruh kata secara tepat, namun subjek masih dapat memahami isi dari suatu bacaan. Hal ini didasarkan pada pendapat Tampubolon (1990), bahwa ketika pembaca tidak membaca keseluruhan kata dalam suatu bacaan, maka pembaca masih bisa memahami 
maksud dari bacaan tersebut. Menurut aliran konstruktivis yang dikemukakan oleh Andersen (dalam Rahim, 2009), bahwa pembaca memahami isi bacaan dengan menghubungkan konteks bacaan dengan pengetahuan yang sebelumnya pembaca miliki. Artinya meskipun dalam suatu teks bacaan tidak membahas secara eksplisit tentang suatu hal, maka pembaca dimungkinkan tetap dapat memahami teks tersebut berdasarkan pengalaman ataupun pengetahuan yang dimiliki. Sebagai contoh pada bacaan 'Pensil Alat Tulis Kita' dalam Tes Kemampuan Membaca Awal, tidak terdapat kalimat atau paragraf yang membahas berbagai macam alat tulis selain pensil. Akan tetapi, kelima subjek penelitian tetap mampu menjawab soal pertanyaan yang berbunyi "sebutkan alat tulis lain selain pensil!". Artinya kemampuan menjawab pertanyaan pada diri subjek didasarkan pada pengalaman ataupun pengetahuan subjek sebelumnya, sehingga subjek mampu memahami isi bacaan.

Adanya peningkatan kecepatan membaca dan pemahaman, maka kemampuan membaca kelima subjek menjadi meningkat. Hal ini didasarkan pada pendapat dari Tampubolon (1990), bahwa kemampuan membaca direkonstruksi oleh 2 aspek, yaitu kecepatan membaca dan pemahaman, sehingga apabila kedua aspek tersebut meningkat, maka kemampuan membaca subjek juga akan mengalami peningkatan. Hal ini ditunjukkan dari hasil analisis deskriptif bahwa ada peningkatan rerata kemampuan membaca kelima subjek setelah diberikan perlakuan sebesar $12,82 \mathrm{kpm}$.
Mengacu pada uraian di atas dapat disimpulkan bahwa pemberian perlakuan dengan metode Analisis Glass mampu meningkatkan kemampuan decoding kelima subjek secara akurat dan otomatis, sehingga menurunkan kesalahan membaca kata yang dilakukan oleh kelima subjek tersebut. Adanya peningkatan kemampuan decoding secara akurat dan otomatis ini juga mengakibatkan peningkatan kecepatan membaca dan pemahaman, sehingga kemampuan membaca permulaan subjek juga mengalami peningkatan yang signifikan.

Berdasarkan hasil analisis yang telah dilakukan, maka dapat disimpulkan bahwa metode Analisis Glass efektif untuk meningkatkan kemampuan membaca permulaan pada anak berkesulitan membaca kelas III SD, sehingga hipotesis yang diajukan dalam penelitian ini diterima.

\section{KESIMPULAN}

Berdasarkan hasil dan pembahasan dapat disimpulkan bahwa ada pengaruh signifikan penggunaan metode Analisis Glass terhadap peningkatan kemampuan membaca permulaan pada anak berkesulitan membaca kelas III Sekolah Dasar. Kemampuan membaca permulaan pada anak berkesulitan membaca kelas III Sekolah Dasar setelah mendapatkan perlakuan meningkat. Hal ini dapat diketahui dari kemampuan membaca permulaan setelah perlakuan lebih baik dari pada sebelum perlakuan, yaitu dengan rerata peningkatan kemampuan membaca permulaan sebesar 12,82 kpm. 
Peningkatan kemampuan membaca permulaan terjadi karena dengan menggunakan metode Analisis Glass pada saat intervensi, mampu menurunkan kesalahan membaca kata subjek penelitian. Berkurangnya atau hilangnya kesalahan dalam membaca kata tersebut pada saat Tes Kemampuan Membaca Permulaan setelah perlakuan, menunjukkan bahwa subjek mengalami peningkatan dalam melakukan proses decoding secara akurat dan otomatis. Semakin akurat dan otomatis dalam melakukan decoding, maka akan meningkatkan kecepatan membaca subjek. Adanya peningkatan kecepatan membaca menjadikan sisa proses mental menjadi semakin besar dan dapat digunakan untuk memahami isi bacaan atau menjawab pertanyaan, sehingga menjadikan pemahaman subjek mengalami peningkatan. Peningkatan pemahaman ini juga dipengaruhi oleh konstruktivis sosial, yaitu kemampuan subjek dalam mengintegrasikan materi bacaan dengan pengetahuan ataupun pengalaman subjek sebelum perlakuan. Adanya peningkatan kecepatan membaca dan pemahaman, pada akhirnya mampu meningkatkan kemampuan membaca subjek.

Hasil penelitian menunjukkan bahwa metode Analisis Glass efektif meningkatkan kemampuan membaca permulaan pada siswa berkesulitan membaca kelas III SD, sehingga saran untuk pihak guru SD 3 Sedayu dan SD 1 Kadipiro untuk dapat melanjutkan penggunaan metode Analisis Glass kepada subjek, sehingga subjek mampu menjadi pembaca yang lancar dan memiliki kemampuan membaca minimal $80 \mathrm{kpm}$ sebagaimana standar minimal kemampuan membaca tingkat SD. Selain itu, metode Analisis Glass juga dapat diterapkan pada siswa yang mengalami kesulitan belajar membaca dan duduk di kelas awal lainnya, yaitu kelas 1 dan 2 SD.

Bagi peneliti selanjutnya disarankan untuk dapat menambah pemberian waktu perlakuan, yaitu lebih dari 5 hari, supaya kemampuan decoding subjek lebih akurat dan otomatis, sehingga akan meniadakan kesalahan dalam membaca kata dan pada akhirnya akan meningkatkan kemampuan membaca permulaan pada anak, yaitu minimal $80 \mathrm{kpm}$ sebagaimana standar minimal kemampuan membaca tingkat SD. Selain itu disarankan kepada peneliti selanjutnya untuk dapat menerapkan metode Analisis Glass pada subjek yang mengalami gangguan membaca yang lebih kompleks, seperti anak dyslexia dan atau anak dengan gangguan mental organik untuk memperkaya ruang lingkup penelitian tentang membaca.

\section{DAFTAR PUSTAKA}

Abdurahman, M. (2010). Pendidikan bagi Anak Berkesulitan Belajar. Jakarta: Rineka Cipta.

Hanifah, I. (2013). Pembelajaran Membaca Permulaan Melalui Metode Analisis Glass Bagi Siswa Berkesulitan Membaca (Reading Dificulties) : Studi Kasus terhadap Siswa Kelas III SDN Cineumbeuy - Kuningan Tahun Akademik 2012/2013.Tesis. Tidak diterbitkan. Bandung: Universitas Pendidikan Indonesia.

Herwell. (2008). Learning Disabilities Handbook. San Fransisco: Jossey Bass. 
Jamaris, M. (2014). Kesulitan Belajar: Perspektif,Asesmen, dan Penanggulangannya Bagi Anak Usia Dini dan Usia Sekolah. Bogor: Ghalia Indonesia.

Kumara, A. (2014). Kesulitan Berbahasa Pada Anak: Deteksi Dini Dan Penanganannya. Yogyakarta: PT Kanisius.

Mather, N., \&Goldstein, S. (2012). Learning Disabilities and Challenging Behaviors: A Guide to Intervention \& Classroom Management. Maryland: Paul $\mathrm{H}$. Brookes Publishing Co.

Monks, F.J., Knoers, A.M.P.,\&Haditono., S.R. (2006). Psikologi Perkembangan: Pengantar Dalam Berbagai Bagiannya. Yogyakarta: Gadjah Mada University Press.

Mulyadi, H. (2010). Diagnosis Kesulitan Belajar dan Bimbingan Terhadap Kesulitan Belajar Khusus. Yogyakarta: Nuha Litera.

Rahim, F. (2009). Pengajaran Membaca di Sekolah Dasar. Jakarta: PT Bumi Aksara.

Seniati, L., Yulianto, A.,\& Setiadi, B.N. (2014). Psikologi Eksperimen. Jakarta: Indeks. 